\title{
Reduced endogenous estrogen delays epididymal development but has no effect on efferent duct morphology in boars
}

\author{
Christopher A Pearl, Eeman At-Taras, Trish Berger and Janet F Roser \\ Department of Animal Science, University of California, Davis, One Shields Avenue, Davis, California 95616, USA \\ Correspondence should be addressed to J F Roser; Email: jfroser@ucdavis.edu \\ T Berger; Email: tberger@ucdavis.edu
}

\begin{abstract}
The study presented herein was designed to test the hypothesis that reduced endogenous estrogen in the boar alters efferent duct morphology, epididymal morphology, and steroid receptor expression. Twenty-eight littermate pairs of boars were treated with Letrozole, an aromatase inhibitor, or with vehicle from 1 week of age until castration at 2 through 8 months. Efferent ducts and epididymides were examined for morphological development and steroid receptor expression. Efferent duct morphology was not different between control and Letrozole-treated animals at any examined age. Androgen receptor (AR), estrogen receptor $\alpha$ (ER $\alpha$ ), and $\beta$ (ERß) were expressed in the epithelial cells of the efferent ducts at all ages; expression was similar in control and treated animals. Morphological development of the caput and corpus was delayed in Letrozole-treated animals, but this delay was transient since morphology was similar between control and treated animals at 8 months. The cauda did not show a delay in development, but was more developed in treated animals at 2 months. $A R, E R \alpha$, and $E R \beta$ were expressed in all three epididymal regions; no difference was observed between control and treated animals. In summary, estrogen appears to be important for development of the epididymis; however, the cauda may be regulated differently than the caput and corpus. Results for the efferent ducts suggest that the normally high endogenous estrogens are not required for regulation of fluid reabsorption in the boar. It also suggests that any ER activation required for maintenance of efferent duct morphology and function is normal in Letrozole-treated boars.
\end{abstract}

Reproduction (2007) 134 593-604

\section{Introduction}

Efferent duct and epididymal function are androgen dependent (Ezer \& Robaire 2002). Androgens are required for maintenance of epithelial morphology (Ezer \& Robaire 2002), protein secretion (Syntin et al. 1999), and regulation of the androgen receptor (AR; Zhu et al. 2000). Recent evidence, however, has demonstrated that estrogen is important for function of the efferent ducts (Hess \& Carnes 2004). The efferent ducts of estrogen receptor alpha knockout $(\alpha E R K O)$ mice fail to properly reabsorb fluid from the testes leading to testicular atrophy and infertility (Hess et al. 1997). Mice and rats treated with $\mathrm{ICl} 182780(\mathrm{ICl})$, an ER antagonist, also failed to properly reabsorb fluid from the lumen of the efferent ducts demonstrating that the infertility of $\alpha E R K O$ mice is due to the lack of ER action, rather than developmental problems (Lee et al. 2000, Oliveira et al. 2001, Cho et al. 2003). In contrast to aERKO mice, aromatase knockout (ARKO) mice, did not exhibit impaired fluid reabsorption in the efferent ductules (Robertson et al. 1999, O'Donnell et al. 2001). Estrogen appears to mediate fluid reabsorption by regulating the expression of ion transporters such as the sodium/hydrogen exchanger-3 (Lee et al. 2001, Zhou et al. 2001) and aquaporins (Oliveira et al. 2005) involved in water movement. The physiological basis for differences between the $\alpha$ ERKO and ARKO models is still unclear although recent work suggests ER activation is a critical difference.

Recent evidence suggests that estrogen may regulate epididymal function. Cauda sperm numbers in both $\alpha \mathrm{ERKO}$ and $\mathrm{ICI}$ treated mice were reduced and the sperm had reduced motility and fertilizing ability (Cho et al. 2003). ICI treated mice had epididymal abnormalities in addition to reduced sperm fertility (Cho et al. 2003). Bonnet monkeys treated with $\mathrm{ICl}$ had reduced sperm motility but, in contrast to mice, sperm numbers were similar between control and treated animals (Shayu et al. 2005). These results suggest that epididymal function is directly affected by inhibiting the actions of estrogen in these males with relatively low endogenous estrogen. Current understanding of efferent duct/epididymal development derives primarily from rodent models. While a few studies have described the morphology of the mature boar efferent ducts and epididymis (Stoffel 
et al. 1991, Stoffel \& Friess 1994), none have characterized the development of the boar efferent ducts or epididymis, a male with relatively high endogenous estrogens, or investigated how the porcine epididymis is regulated by steroid hormones.

Estrogens and androgens exert their effects by binding to specific receptors in the target tissue. Both ER $\alpha$ and $E R \beta$, in addition to $A R$, are expressed in cells from the efferent ducts to the cauda in numerous species, although differences exist in regional localization (Hess \& Carnes 2004). AR and ER $\beta$ have been localized to the epithelium of the efferent ducts and all three regions of the adult epididymis in numerous species (Nie et al. 2002, Yamashita 2004, Parlevliet et al. 2006), including the pig (Pearl et al. 2006). ER $\alpha$ is expressed in the efferent ducts of all species studied but epididymal expression is much more variable among species (Hess \& Carnes 2004) and even within a species like the horse (Parlevliet et al. 2006). The developmental profile of morphology and steroid regulation of $A R, E R \alpha$, and $E R \beta$ expression in the efferent ducts and epididymis of the boar is unknown. Given the variation that exists among species, detailing the localization of ERs and AR in the boar is important before conclusions are reached about the role of estrogens in the epididymis and efferent ducts of this male with high endogenous estrogen levels.

Studies on the physiological effects of estrogen have been facilitated by the development of specific inhibitors of aromatase, the enzyme responsible for estrogen synthesis. Aromatase in the boar is found primarily in the Leydig cells of the testis (Conley et al. 1996, Mutembei et al. 2005) and estrogen is delivered to the efferent ducts and epididymis through the tubules or via the blood. Circulating estrogen concentrations in the boar $(\sim 200 \mathrm{pg} / \mathrm{ml})$ are relatively high compared with males of other species (2-50 pg/ml; Ford 1983, Hess \& Carnes 2004). Our laboratories have previously demonstrated that treatment with Letrozole, an aromatase inhibitor, significantly reduces aromatase activity in the boar testis leading to reduced testicular and systemic estrogen concentrations without changing testosterone or gonadotropin concentrations (At-Taras et al. 2006a). This is an important feature of our model as $\alpha$ ERKO mice have increased testosterone and gonadotropin concentration, and ARKO mice have increased testosterone and luteinizing hormone ( $\mathrm{LH}$ ) concentrations ( $\mathrm{O}^{\prime}$ Donnell et al. 2001). Boars treated weekly with Letrozole throughout their life showed a delayed testicular development but at 8 months, testis size and total sperm production were increased (At-Taras et al. 2006b). Cauda epididymal sperm numbers were reduced in these boars (McCarthy et al. 2006) even though testis size and sperm production were increased. In vitro fertilizing ability of cauda epididymal sperm was reduced in Letrozole-treated animals compared with control animals at 6 and 7 months but was similar at 8 months (McCarthy et al. 2006). Other sperm parameters such as percentage of motile sperm, head morphology, and the ability to undergo the acrosome reaction were unaffected by treatment. The initial reduction in cauda sperm fertilizing ability and sperm numbers suggests that reducing endogenous estrogen may affect efferent duct and epididymal development and function in the boar; however, this was not examined in our previous reports.

Here we investigate the effects of reduced endogenous estrogen production on the efferent ducts and epididymis in Letrozole-treated boars. It was hypothesized that reduced endogenous estrogen production would alter efferent duct and epididymal development and steroid receptor expression. To test this hypothesis, the efferent ducts and epididymis of control and Letrozole-treated boars were examined for changes in morphology and steroid receptor expression.

\section{Results \\ Morphology}

The tubule diameter, lumen diameter, and epithelial cell height of the efferent ducts in control boars were $67 \pm 29 \mu \mathrm{m}, 43 \pm 27 \mu \mathrm{m}$, and $12 \pm 2 \mu \mathrm{m}$ respectively, at 2 months of age and increased to $205 \pm 28 \mu \mathrm{m}$ $(P<0.0001), 147 \pm 26 \mu \mathrm{m}(P=0.0001)$, and $21 \pm 2 \mu \mathrm{m}$ $(P=0.02)$ respectively, at 5 months of age without further increase at 8 months (Fig. 1). No differences were seen in tubule diameter, lumen diameter, or epithelial height of efferent ducts between control and Letrozole-treated animals (Fig. 1).

In the caput (Fig. 2), tubule and lumen diameter of control animals significantly increased from 2 to 5 months $(P<0.0001)$ without further significant increases at 8 months. In treated animals, tubule diameter increased between 2 and 5 months $(P<0.0001)$ and further increased between 5 and 8 months $(P=0.0002)$; lumen diameter did not increase between 2 and 5 months but did increase between 5 and 8 months in treated boars $(P=0.004)$. Tubule and lumen diameter were similar between control and Letrozole-treated animals except at 5 months when the tubule and lumen diameters were smaller in treated animals $(P \leq 0.002)$. Epithelial height significantly increased from 2 to 5 months $(P<0.0001)$, without further increases at 8 months in both control and Letrozoletreated animals. Epithelial height was not different between control and treated animals at any age.

In the corpus (Fig. 3), tubule and lumen diameter of control animals significantly increased from 2 to 5 months $(P<0.0001)$ without further significant increases at 8 months. In treated animals, tubule and lumen diameter increased between 2 and 5 months $(P \leq 0.018)$ and further increased between 5 and 8 months $(P \leq 0.017)$. Epithelial height significantly increased from 2 to 5 months $(P<0.0001)$, without further increases at 8 months in both control and Letrozole-treated animals. Tubule 

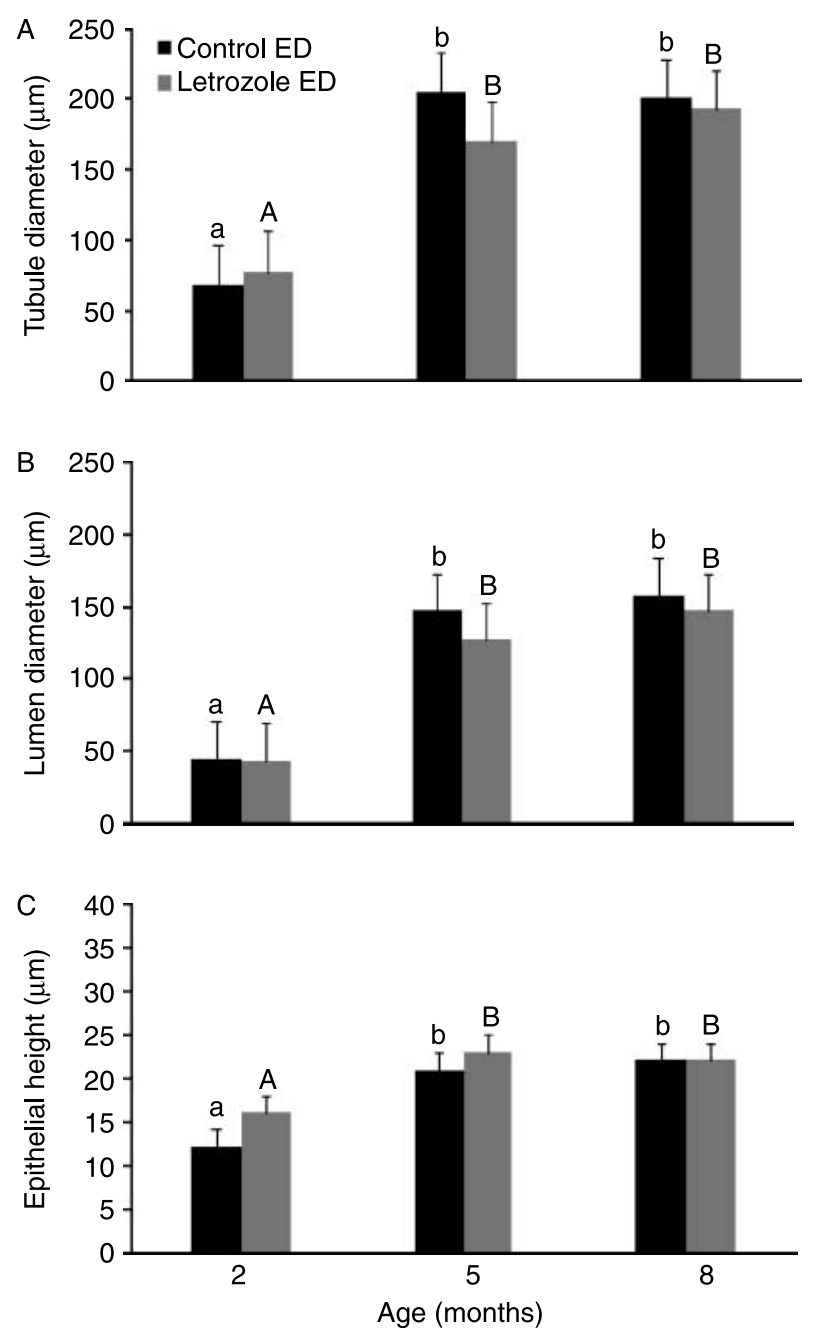

Figure 1 (A) Tubule diameter, (B) lumen diameter, and (C) epithelial height of efferent ducts in control and Letrozole-treated boars. Tubule diameter, lumen diameter, and epithelial height increased with age. No difference was observed between control and treated animals.

LSMeans \pm pooled S.E.M. of untransformed data is presented; statistics were performed on log-transformed data. a versus $b$ (controls), $P<0.0001 ; A$ versus B (treated), $P \leq 0.02$.

diameter, lumen diameter, and epithelial height were similar between control and Letrozole-treated animals at all ages.

In the cauda (Fig. 4), tubule and luminal diameter significantly increased from 2 to 5 months in control $(P<0.0001)$ and treated $(P \leq 0.046)$ animals without further significant increases at 8 months. Epithelial height did not increase with age in the cauda in either control or Letrozole-treated animals $(P>0.5)$. Tubule diameter, lumen diameter, and epithelial height were similar between control and Letrozole-treated animals except at 2 months when the tubule diameter $(P<0.0001)$, lumen diameter $(P<0.0001)$, and epithelial height $(P<0.04)$ were increased in treated animals.

Paired epididymal weight increased from $8.10 \pm 0.7 \mathrm{~g}$ at 2 months of age to $153.8 \pm 9.8 \mathrm{~g}$ at 8 months of age in
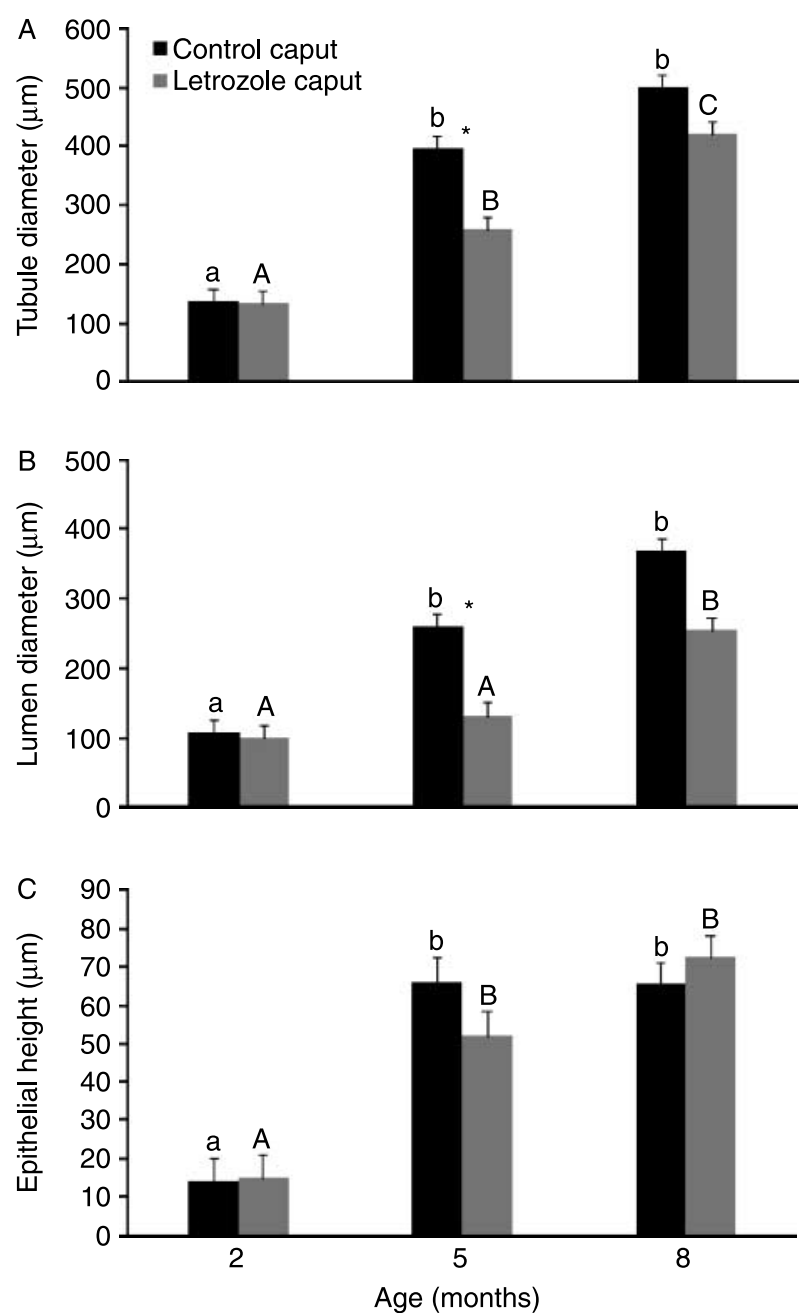

Figure 2 (A) Tubule diameter, (B) lumen diameter, and (C) epithelial height of caput epididymis in control and Letrozole-treated boars. An increase with age was observed in both control and treated boars although treated animals were delayed compared with controls. LSMeans \pm pooled S.E.M. of untransformed data is presented; statistics were performed on log-transformed data. a versus $b$ (control), $P<0.0001 ; A$ versus $B$ versus $C$ (treated), $P \leq 0.004$. ${ }^{*}$ (control versus treated), $P \leq 0.002$.

control animals $(P<0.0001)$. Epididymal weights were similar between control and treated animals (Fig. 5) except at 7 months of age when the weight was increased in control animals $(P=0.005)$.

\section{Steroid concentrations}

Our previous reports show that testicular aromatase activity was reduced by $83 \%$ overall in Letrozole-treated boars with a $92 \%$ reduction at 2 months of age $(168.1 \pm 16.5 \mathrm{pmol}$ $(\mathrm{mg} /$ protein)/h in control boars versus $16.5 \mathrm{pmol}$ (mg/protein)/h in treated boars) (At-Taras et al. 2006a). Testicular and systemic concentrations of estradiol were significantly reduced in Letrozole-treated boars; however, testosterone concentrations were unchanged (At-Taras et al. 2006a). 

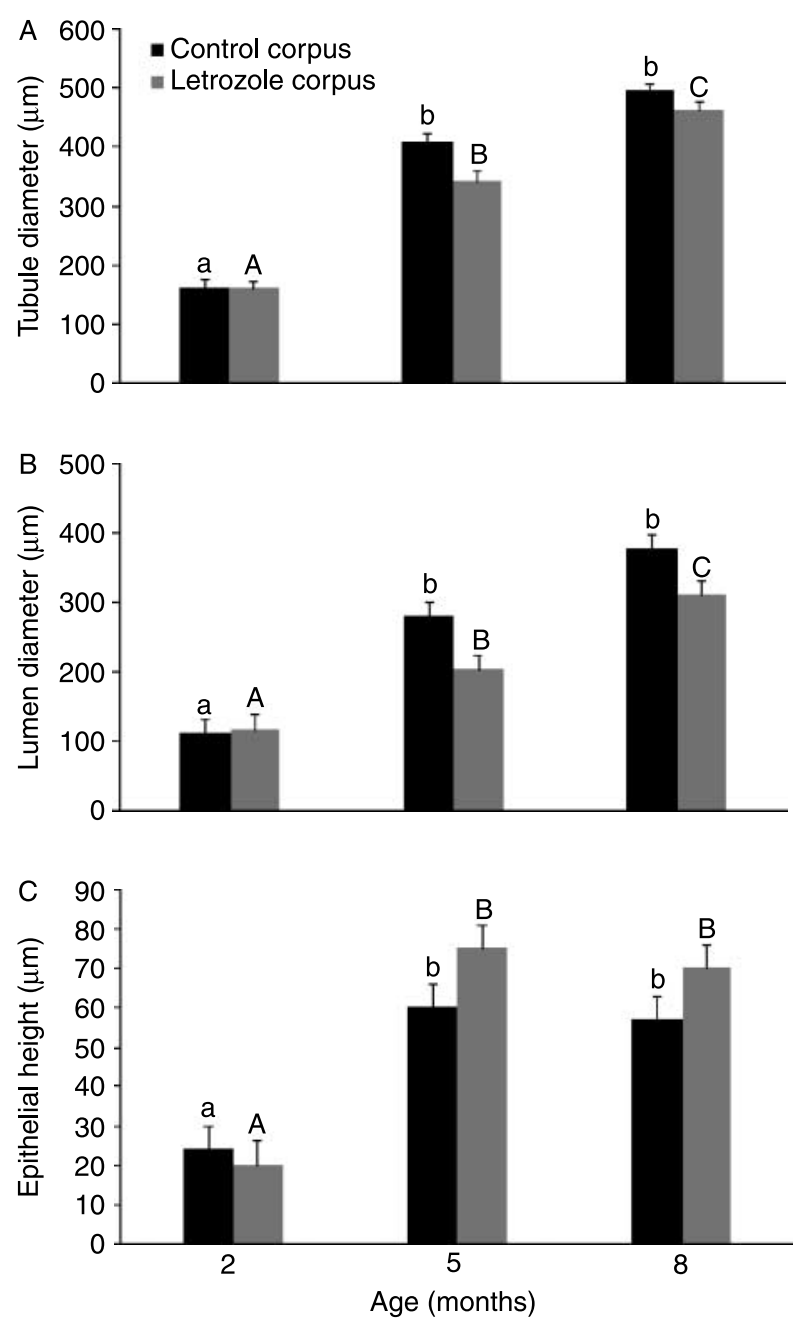

Figure 3 (A) Tubule diameter, (B) lumen diameter, and (C) epithelial height of corpus epididymis in control and Letrozole-treated boars. An increase with age was observed in both control and treated boars although treated animals were delayed compared with controls. LSMeans \pm pooled S.E.M. of untransformed data is presented; statistics were performed on log-transformed data. a versus $b$ (control), $P<0.0001 ; A$ versus B versus C (treated), $P \leq 0.018$.

Here we report the concentrations of estradiol and testosterone in the efferent ducts and epididymis of these Letrozole-treated boars.

Estradiol concentrations were decreased in the efferent ducts and epididymis of Letrozole-treated animals compared with control animals throughout development (Table 1; data from 2 and 8 months presented). In control animals, the concentration of estradiol in the efferent ducts was higher than the epididymis at 2 months $(P<0.05)$ but this was not observed in other age groups. Concentrations were similar among the epididymal regions with no gradient of increasing or decreasing estradiol concentrations observed in control or Letrozole-treated boars. Estradiol concentrations in the efferent ducts were highest at 2 months $(P<0.05)$; no differences were observed in the concentrations of estradiol in the epididymis with age $(P>0.05)$.
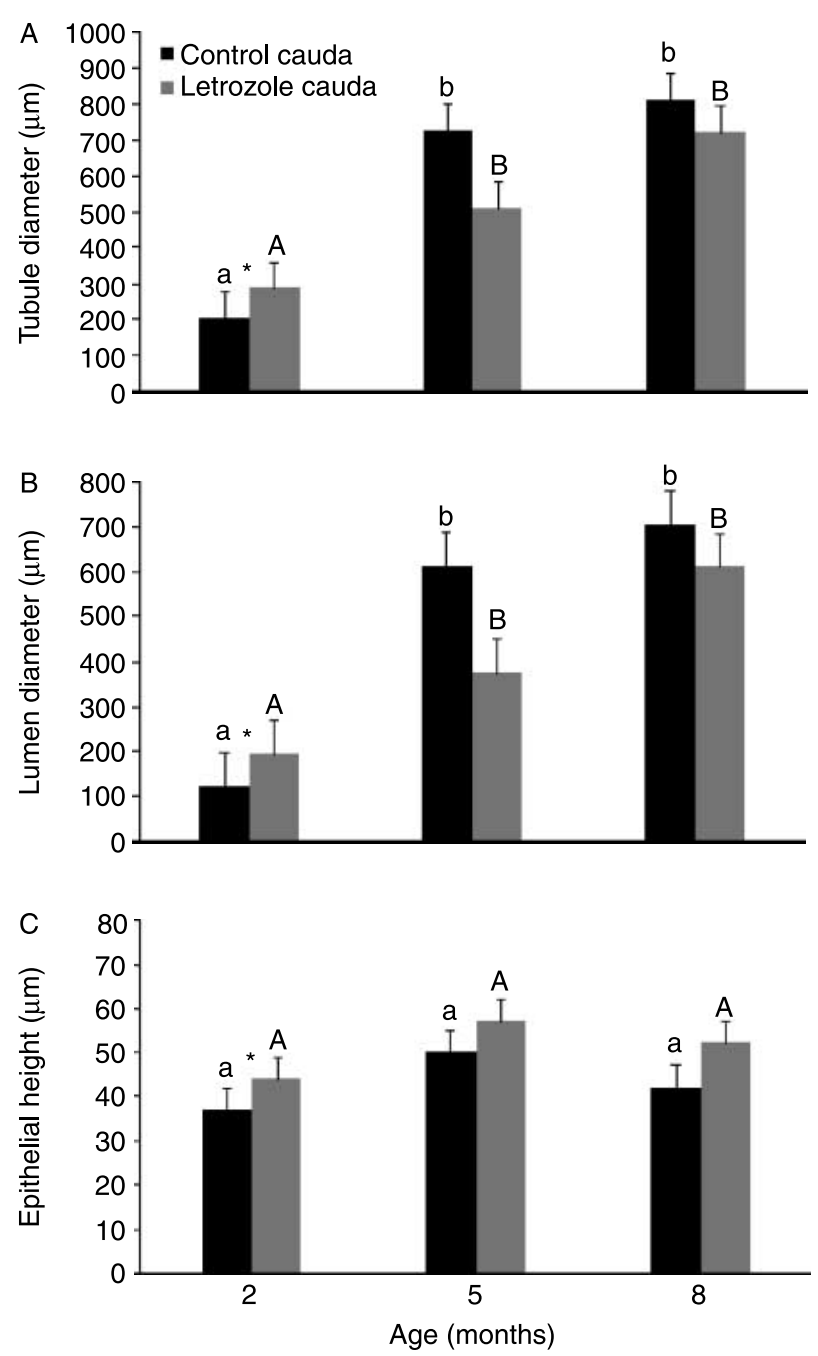

Figure 4 (A) Tubule diameter, (B) lumen diameter, and (C) epithelial height of cauda epididymis in control and Letrozole-treated boars. An increase with age was observed in tubule and lumen diameter in both control and treated boars. Tubule diameter, lumen diameter, and epithelial height were increased at 2 months of age in treated animals. LSMeans \pm pooled S.E.M. of untransformed data is presented; statistics were performed on log-transformed data. a versus $b$ (control), $P<0.0001$; A versus B (treated), $P<0.05$. * (control versus treated), $P \leq 0.04$.

Testosterone concentrations were similar between control and Letrozole-treated animals in the efferent ducts and epididymis throughout development except in the caput at 2 months (Table 1 ; data from 2 and 8 months presented). The concentration of testosterone in the efferent ducts was not different from the epididymis in control and Letrozole-treated animals. Concentrations were similar among the epididymal regions with no overall gradient of increasing or decreasing testosterone concentrations observed in control or Letrozole-treated boars. No differences were observed in the concentrations of testosterone in the efferent ducts or epididymis with age $(P>0.05)$. 


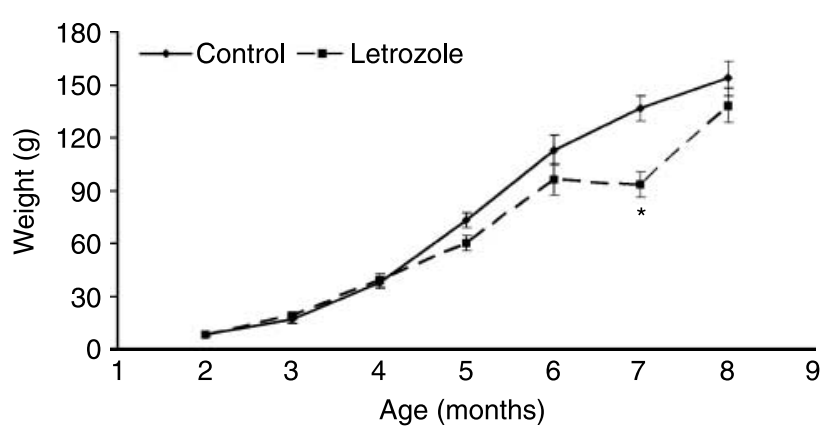

Figure 5 Weight of epididymides (LSMeans \pm pooled S.E.M.) in control and Letrozole-treated boars. A difference in weight was observed at 7 months between control and treated boars. *(control versus treated), $P=0.005$.

\section{Steroid receptor localization}

The epithelial cells of the efferent ducts were positive for $A R$, ER $\alpha$, and $E R \beta$ (Fig. 6) throughout development in control animals; no age differences were observed. Immunostaining for $A R, E R \alpha$, and $E R \beta$ was similar between control and Letrozole-treated boars in the efferent ducts. Negative controls incubated with NRS (AR and $E R \alpha$ ) or mouse $\lg G(E R \beta)$ instead of primary antibody did not exhibit immunostaining.

At 2 months, AR was present in the epithelial cell nuclei of the caput, corpus, and cauda and continued to be present in the nuclei of principal and basal cells of the caput, corpus, and cauda from 3 to 8 months (Fig. 7). No age difference was seen in AR immunostaining. Intermittent immunostaining of smooth muscle was also seen in all three regions throughout development. Immunostaining for AR was similar between control and Letrozole-treated boars in the epididymis.

At 2 months, ER $\alpha$ was present in most epithelial cell nuclei of the caput, corpus, and cauda and continued to be present in the nuclei of principal and basal cells of the caput, corpus, and cauda from 3 to 8 months (Fig. 8). However, at 8 months of age, fewer cells were positive in the corpus and cauda compared with younger boars. Immunostaining for $\mathrm{ER} \alpha$ was similar between control and Letrozole-treated boars in the epididymis.
At 2 months, ER $\beta$ was present in the epithelial cell nuclei of the caput, corpus, and cauda and continued to be present in the nuclei of principal and basal cells of the caput, corpus, and cauda from 3 to 8 months (Fig. 9). No age difference was observed in ER $\beta$ immunostaining. Immunostaining for ER $\beta$ was similar between control and Letrozole-treated boars in the epididymis.

\section{Steroid receptor $m R N A$}

$E R \propto m R N A$ in the efferent ducts of treated animals was 9 -fold higher $(P<0.05)$ than control animals at 2 months and was 38 -fold higher $(P<0.005)$ than control animals at 8 months (Fig. 10). However, this difference in mRNA did not correlate with protein levels as ER $\alpha$ protein in the efferent ducts at 8 months was similar between control and Letrozole-treated animals as determined by Western blot analysis (Fig. 11). ER $\alpha$ mRNA was unchanged in caput and cauda but was eightfold less in the corpus of 2 -month treated animals compared with control animals $(P<0.05)$. Significant differences were not observed in $E R \alpha$ mRNA in the caput, corpus, or cauda of treated animals at 8 months, nor were significant differences observed in AR or ER $\beta$ mRNA in the epididymis or efferent ducts of treated animals at 2 or 8 months (data not shown).

\section{Discussion}

Previously, we reported that boars treated weekly with Letrozole have reduced testicular and circulating concentrations of estrogens without changes in testosterone or gonadotropin ( $\mathrm{LH}$ and follicle-stimulating hormone) concentrations (At-Taras et al. 2006a). This contrasts with the $\alpha E R K O$ and ARKO mouse models in which testosterone and gonadotropin concentrations are increased (O'Donnell et al. 2001). Here we demonstrate that estrogen concentrations are also reduced in the efferent ducts and epididymis of Letrozole-treated boars. Cauda epididymal sperm numbers were reduced in Letrozole-treated boars at 8 months of age (McCarthy et al. 2006) even though testis size and hence total sperm

Table 1 Concentrations of estradiol (pg/mg protein) and testosterone (ng/mg protein) in the efferent ducts and epididymis of control and Letrozoletreated boars. Estradiol concentrations were reduced in Letrozole-treated animals. Testosterone concentrations were similar between control and Letrozole-treated animals.

\begin{tabular}{|c|c|c|c|c|c|c|}
\hline Steroid & Age & Treatment & ED & Caput & Corpus & Cauda \\
\hline Estradiol & 2 & Control & $32 \pm 6.6$ & $4.5 \pm 4.7$ & $5.9 \pm 4.7$ & $3.1 \pm 4.7$ \\
\hline Estradiol & 2 & Letrozole & $0.47 \pm 6.6^{*}$ & $1.5 \pm 4.7^{*}$ & $1.8 \pm 4.7^{*}$ & $1.2 \pm 4.7^{*}$ \\
\hline Estradiol & 8 & Control & $2.3 \pm 0.2$ & $1.1 \pm 0.2$ & $1.4 \pm 0.2$ & $1.2 \pm 0.2$ \\
\hline Estradiol & 8 & Letrozole & $0.9 \pm 0.2 *$ & $0.5 \pm 0.2 *$ & $0.5 \pm 0.2 *$ & $0.7 \pm 0.2$ \\
\hline Testosterone & 2 & Control & $0.34 \pm 0.09$ & $0.12 \pm 0.07$ & $0.17 \pm 0.07$ & $0.11 \pm 0.07$ \\
\hline Testosterone & 2 & Letrozole & $0.2 \pm 0.09$ & $0.37 \pm 0.07^{*}$ & $0.29 \pm 0.07$ & $0.13 \pm 0.07$ \\
\hline Testosterone & 8 & Control & $0.25 \pm 0.04$ & $0.16 \pm 0.04$ & $0.19 \pm 0.04$ & $0.15 \pm 0.04$ \\
\hline Testosterone & 8 & Letrozole & $0.15 \pm 0.04$ & $0.15 \pm 0.04$ & $0.15 \pm 0.04$ & $0.14 \pm 0.04$ \\
\hline
\end{tabular}

LSMeans \pm S.E.M. of untransformed data is presented; statistics were performed on log-transformed data. * Different from same aged control at $P<0.05$. 

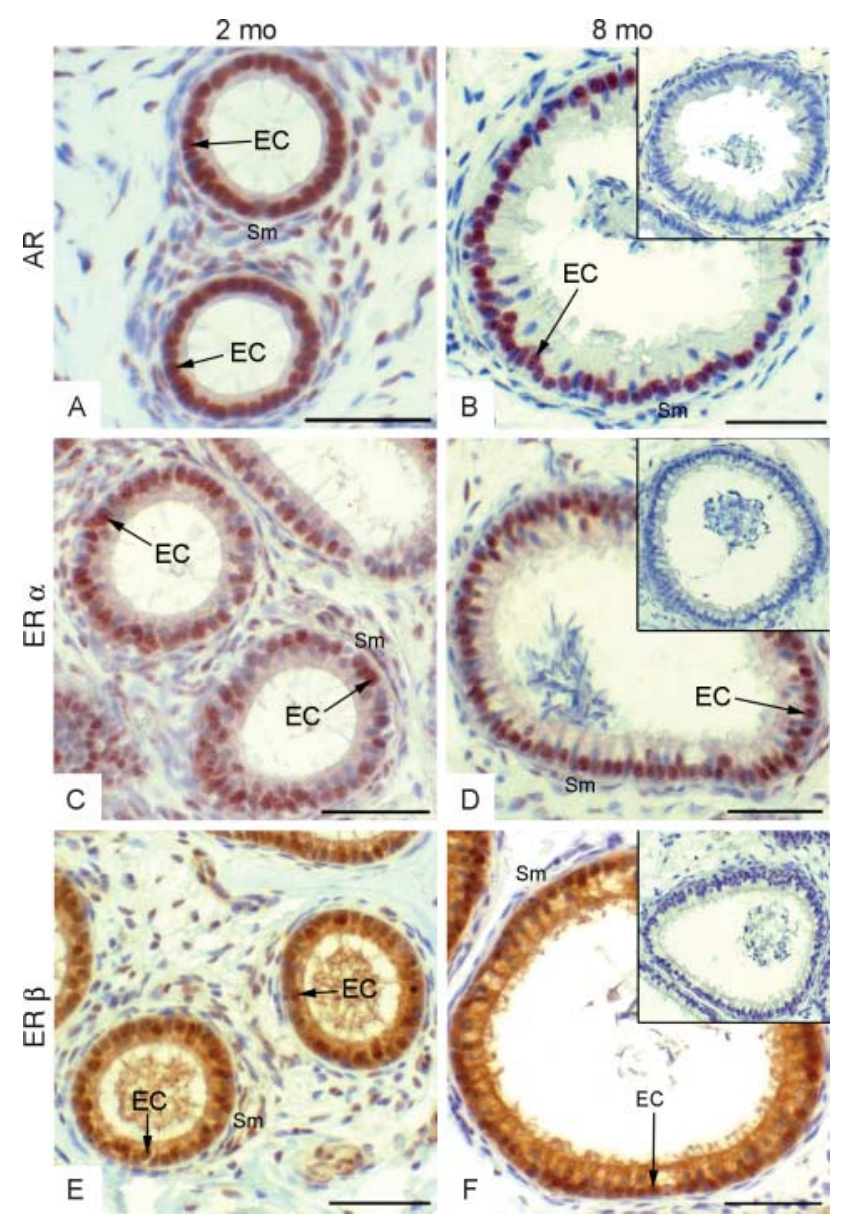

Figure $6 \mathrm{AR}, E R \alpha$, and $E R \beta$ immunostaining in 2- and 8-month boar efferent ducts. Epithelial cells were positive for $(A$ and $B) A R,(C$ and $D)$ $E R \alpha$, and $(E$ and $F) E R \beta$ at both $2(A, C$ and $E)$ and $8(B, D$ and $F)$ months. Intermittent staining was present in smooth muscle for all three receptors. No difference was observed between control and Letrozoletreated boars. No immunostaining was present in negative controls (insets). EC, epithelial cell; Sm, smooth muscle. Bars, $50 \mu \mathrm{m}$.

production were increased (At-Taras et al. 2006b). Here we report the effects of reduced endogenous estrogen on the efferent ducts and epididymis in these boars.

To our knowledge, this is the first report describing the development of the efferent ducts in boars and to evaluate the role of estrogen in this process. The efferent ducts, whose primary function is fluid reabsorption, connect the rete testis to the epididymis and consist of principal and ciliated cells (Stoffel \& Friess 1994). In this study, tubule diameter, lumen diameter, and epithelial height of the efferent ducts increased from 2 to 5 months without further increases up to 8 months in both control and treated animals. The tubule diameter and epithelial heights at 8 months reported here are similar to previously reported values for mature boar efferent ducts (Stoffel \& Friess 1994). Puberty occurs between 4 and 5 months in boars, therefore, it is not surprising to see morphological changes occurring during this time when fluid and sperm first begin to enter the efferent
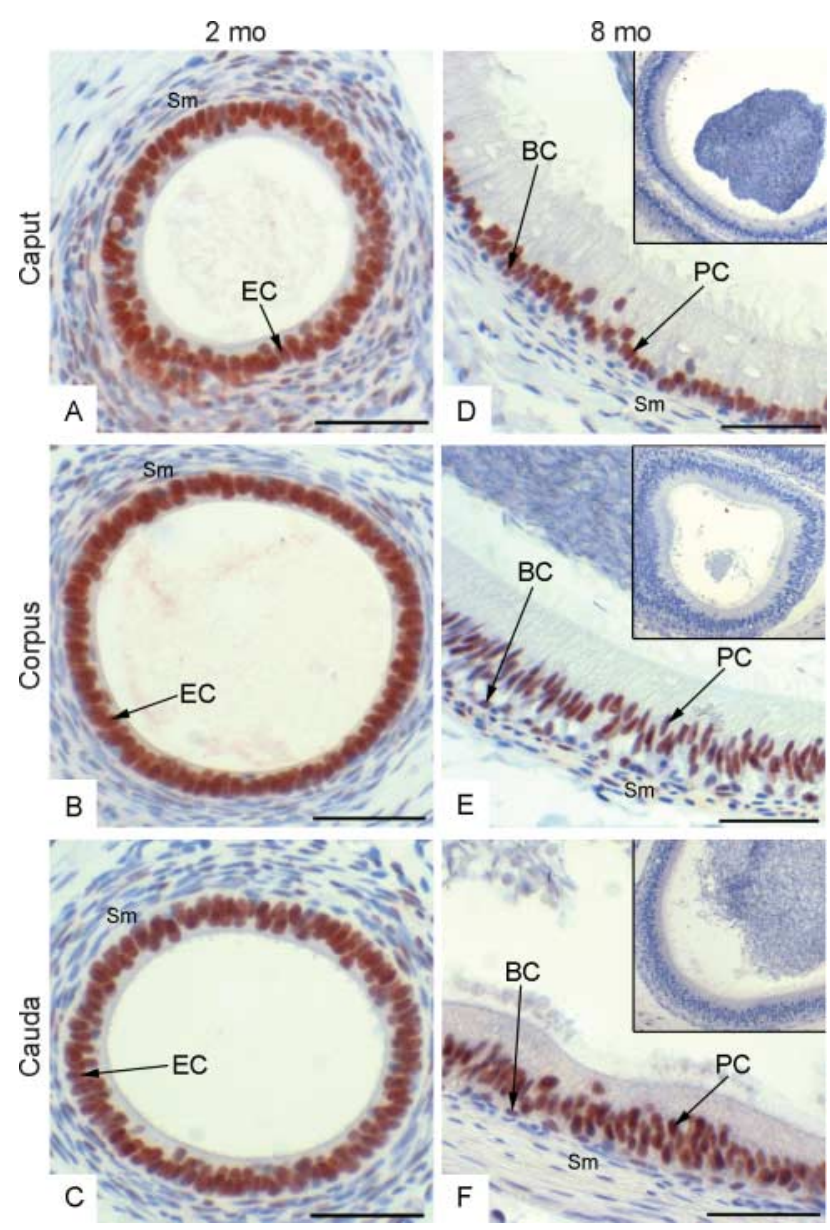

Figure 7 Androgen receptor in 2- and 8-month control epididymis. At 2 months, epithelial cells were positive in the (A) caput, (B) corpus and (C) cauda. At 8 months, principal and basal cells were positive in the (D) caput, (E) corpus and (F) cauda. Intermittent staining was present in smooth muscle. Immunostaining was similar in control and Letrozoletreated boars. No immunostaining was present in negative controls (insets). EC, epithelial cell; PC, principal cell; BC, basal cell; Sm, smooth muscle. Bars, $50 \mu \mathrm{m}$.

ducts. Previous studies in $\alpha$ ERKO mice have demonstrated that inhibition of estrogen action leads to impaired fluid reabsorption by the efferent ducts resulting in increased lumen diameter and decreased epithelial height (Lee et al. 2000). ARKO mice, however, do not show these same defects of efferent duct function (Robertson et al. 1999). In the present study, tubule diameter, luminal diameter, and epithelial height were similar between control and Letrozole-treated boars at all ages examined. It is possible that a threshold level of estradiol is needed to maintain normal efferent duct morphology and function and that treated boars, while having significantly reduced estradiol concentrations, were still above that threshold. Results presented here for boars are similar to the results found in ARKO mice, which do not show abnormal efferent ducts under the complete elimination of estrogen. 

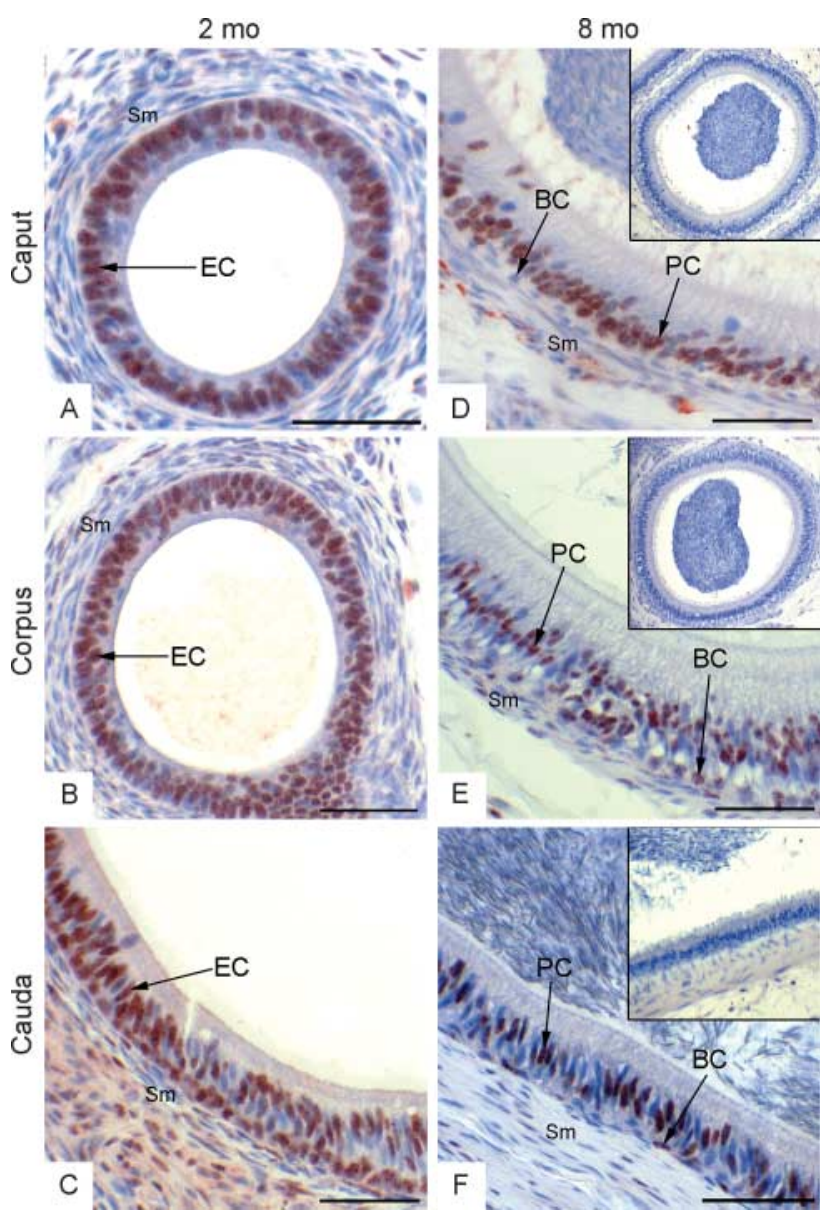

Figure 8 Estrogen receptor alpha in 2- and 8-month control epididymis. At 2 months, epithelial cells were positive in (A) caput, (B) corpus, and (C) cauda. At 8 months, principal cells were positive in (D) caput. Principal cells and some basal cells were positive in the (E) corpus and (F) cauda. Intermittent staining was present in the smooth muscle. Immunostaining was similar in control and Letrozoletreated boars. No immunostaining was present in negative controls (insets). EC, epithelial cell; PC, principal cell; BC, basal cell; Sm, smooth muscle. Bars, $50 \mu \mathrm{m}$.

Estrogen, acting through its receptors, appears to mediate fluid reabsorption in the mouse efferent duct by regulating the expression of ion transporters (Lee et al. 2001, Zhou et al. 2001) involved in water movement such as the sodium/hydrogen exchanger-3 (NHE3) and aquaporins (Oliveira et al. 2005). However, efferent duct expression of $E R \alpha, E R \beta$, and AR protein was similar between control and treated boars in this study. Proteins and ion channels involved in water movement may be either constitutively expressed or regulated by androgens or other testicular factors in addition to estrogens in the boar. ER $\alpha$ was reported to be activated in the absence of estrogen by other factors like EGF (Coleman \& Smith 2001, Marquez et al. 2001). Aquaporin-1 is constitutively expressed and aquaporin-9 is regulated by both estrogen and DHT in the rat efferent ducts (Oliveira et al. 2005). Recently, $5 \alpha$-androstane-3 $\beta, 17 \beta$-diol (3-beta-
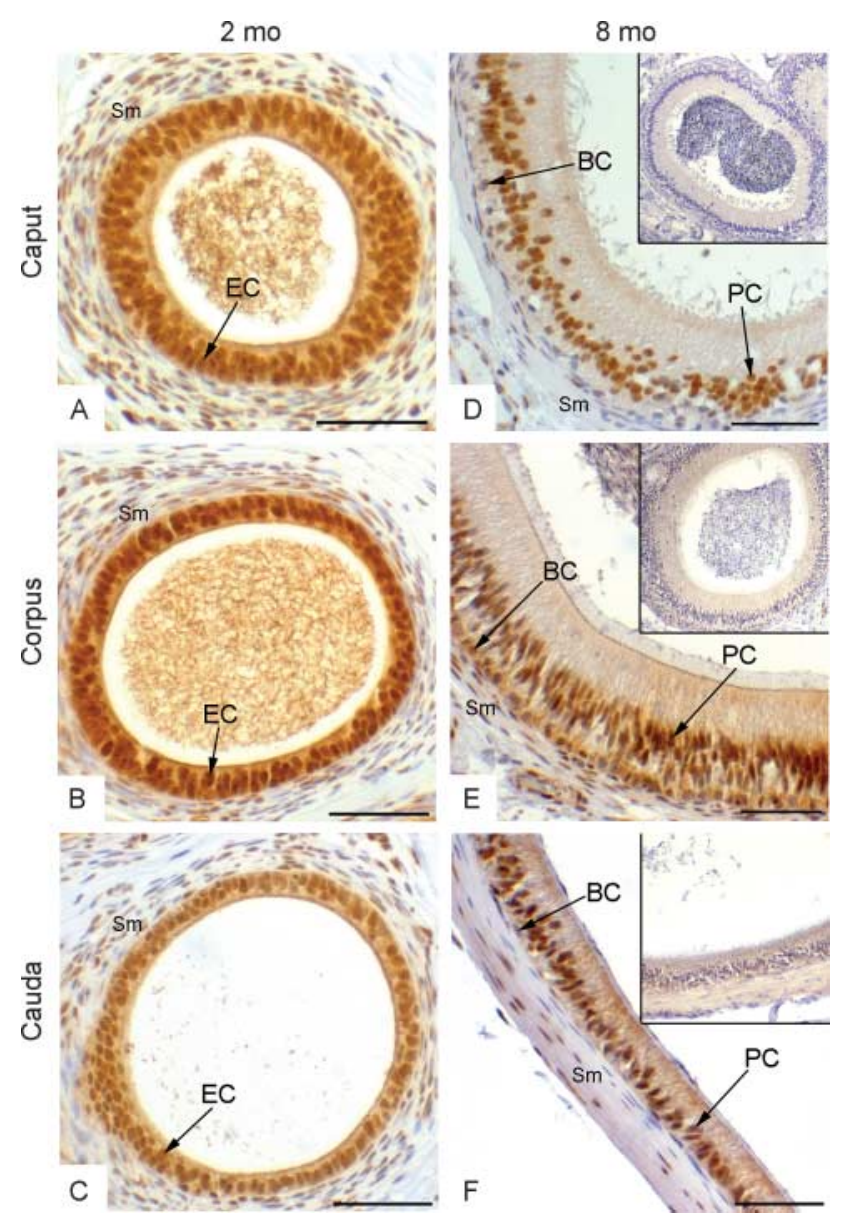

Figure 9 Estrogen receptor beta in 2- and 8-month control epididymis. At 2 months, epithelial cells were positive in (A) caput, (B) corpus, and (C) cauda. At 8 months, principal and basal cells in (D) caput,

(E) corpus, and (F) cauda were positive. Smooth muscle was positive in both age groups. Immunostaining was similar in control and Letrozoletreated boars. No immunostaining was present in negative controls (insets). EC, epithelial cell; PC, principal cell; BC, basal cell; Sm, smooth muscle. Bars, $50 \mu \mathrm{m}$.

diol), a dihydrotestosterone (DHT) metabolite was also found to restore aquaporin-9 expression after castration, similar to DHT and estradiol (Picciarelli-Lima et al. 2006). This 3-beta-diol bound to both $E R \alpha$ and $E R \beta$ with a higher affinity for ER $\beta$ (Kuiper et al. 1997). Furthermore, the estrogen response element in genes of the ARKO mouse was functional (Hayashi et al. 2006) despite the absence of estrogen. If $E R \alpha$ and $E R \beta$ are activated by 3-beta-diol or other ligands that were unaltered by treatment, then the downstream effects of these receptors on aquaporins and ion transporters, like NHE3, would be unaffected. These results suggest that the regulation of fluid reabsorption in the efferent ducts of boars does not require estrogen similar to the ARKO mouse. Activation of ERs is blocked in ERKO mice, but likely remains intact in Letrozole-treated boars and ARKO mice. Maintenance of efferent duct development during aromatase inhibition supports the hypothesis 


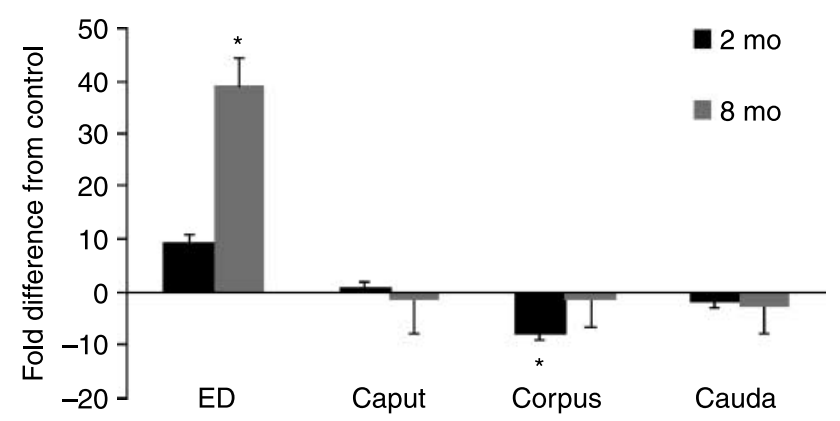

Figure 10 Fold difference in ER $\alpha$ mRNA in treated animals compared with control animals at 2 and 8 months. ER $\alpha$ mRNA was increased in the efferent ducts at 2 and 8 months. $* P<0.05$.

developed from the ARKO model that ER activation rather than estrogen itself is required for normal efferent duct development. Therefore, it is possible that ER activation under reduced estrogen conditions is maintained by other ligands in the efferent ducts and this could explain the differences between the Letrozoletreated boars or ARKO mice and the $\alpha$ ERKO mice.

AR expression was similar between control and Letrozole-treated boars as anticipated, since testosterone concentrations were similar in control and Letrozoletreated boars. Expression of ER $\alpha$ and ER $\beta$ protein was similar between control and Letrozole-treated boars despite the differences in estradiol concentrations. ER $\alpha$ mRNA in the efferent ducts of treated boars was increased relative to controls at 2 and 8 months but this was not accompanied by a corresponding increase in $E R \alpha$ protein. A similar result was found for $E R \alpha$ in 30-day-old ICl treated bonnet monkeys (Shayu et al. 2005). Protein turnover of ER $\alpha$ may be higher in the efferent duct of Letrozole-treated boars. In contrast to $E R \alpha, E R \beta m R N A$ in treated animals was not altered relative to control animals suggesting that $E R \alpha$ and $E R \beta$ protein expression in the boar efferent ducts are regulated differently and possibly by factors other than estrogen. Testosterone was reported to regulate ER expression during development in the rabbit epididymis (Toney \& Danzo 1988) and can upregulate ER $\beta$ in the rat prostrate (Asano et al. 2003). DHT increased ER $\beta$ expression in the endometrium of gilts (Cardenas \& Pope 2005). Therefore, ER $\alpha$ and $E R \beta$ expressions in the boar efferent ducts may be regulated by androgens.

In control and Letrozole-treated animals, tubule and lumen diameter increased with age in all three epididymal regions, while epithelial height increased with age in the caput and corpus. The smaller tubule and lumen diameter in the caput and corpus at 5 months in treated animals followed by significant increases between 5 and 8 months suggests a delay in development of these regions as a result of reduced endogenous estrogen. The delay was transient, however, as tubule and lumen diameters were similar between control and Letrozole-treated animals at 8 months. Values reported
A
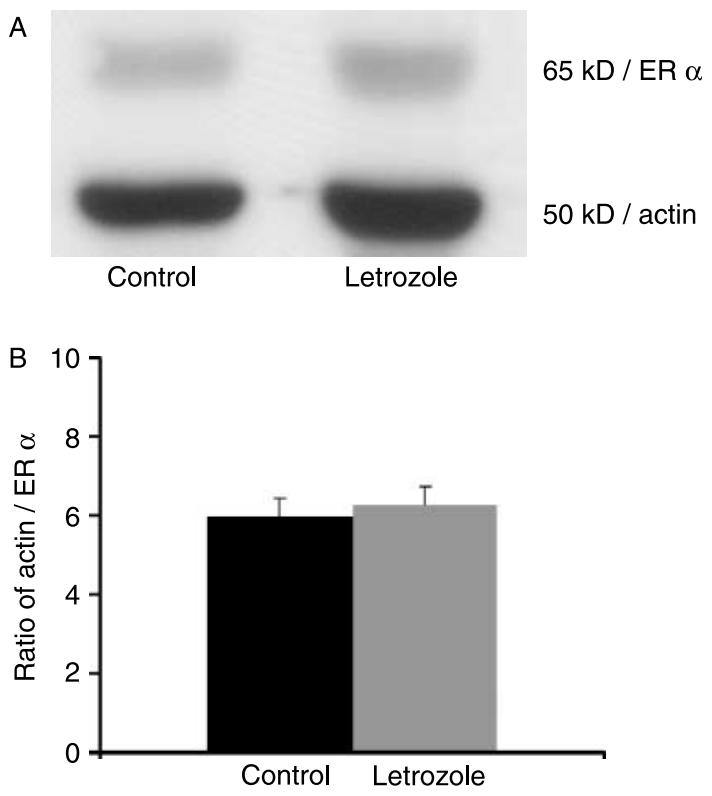

Figure 11 Western blot analysis of ER $\alpha$ in the efferent duct of 8-month boars. No difference was observed in the levels of ER $\alpha$ protein between control and Letrozole-treated boars (values are LSMeans \pm S.E.M. of four boars). (A) Representative lanes; (B) densitometric analysis.

here for 8-month animals are similar to values previously reported for mature boars (Stoffel \& Friess 1994). In both control and treated animals, tubule and lumen diameter increase from caput to cauda at 8 months while epithelial height decreases from caput to cauda. This pattern from caput to cauda is similar to previous reports for the boar (Stoffel \& Friess 1994) and other species (Goyal 1985, Goyal \& Williams 1991, Calvo et al. 1999).

The delay in development may be a direct result of decreased estrogen stimulation or the result of decreased signaling from other testicular factors and sperm. A delay in testicular development was also observed in these Letrozole-treated boars (At-Taras et al. 2006b). This delay resulted in fewer sperm in the epididymis and perhaps other testicular factors that may be involved in epididymal development during puberty. Luminal fluid factors from the testis play a role in epididymal development (Rodriguez et al. 2002) and it is possible that the caput and corpus require these factors for tubule expansion and epithelial differentiation. A delay in development was not observed in the cauda; in contrast, tubule diameter, lumen diameter, and epithelial height were increased at 2 months of age. These results suggest that the cauda is regulated differentially than the caput and corpus during development and may be less dependent on testicular factors.

Epididymal weight increased with age and was similar between control and Letrozole-treated animals, except at 7 months when it was significantly less. Morphology of the caput, corpus, and cauda at 7 months was similar between control and Letrozole-treated boars. Our labs have previously reported significantly reduced sperm 
numbers in the cauda epididymis of Letrozole-treated boars at 7 months (McCarthy et al. 2006) and this likely accounts for the difference in epididymal weight. Sperm numbers were still reduced at 8 months, although not as severely as at 7 months. The lack of difference in epididymal weight at 8 months supports the hypothesis that the effect of Letrozole treatment on sperm numbers is transient and recovering at 8 months.

The localization of $E R \alpha, E R \beta$, and $A R$ in the epididymis of mature animals has been reported for numerous species; however, the expression of these receptors throughout development has been described in only a few species. In this study $E R \alpha, E R \beta$, and $A R$ were expressed in the caput, corpus, and cauda of the boar from 2 to 8 months of age. No difference was seen in the epididymis between control and Letrozole-treated animals for $E R \alpha, E R \beta$, or AR. Since estradiol concentrations were significantly reduced in treated animals, $E R \alpha$ and $E R \beta$ in the epididymis may be regulated by androgens or other testicular factors that were not altered by treatment. The developmental expression pattern reported here is consistent with results found for AR and ER $\beta$ in other species (Goyal et al. 1997a, Atanassova et al. 2001, Nie et al. 2002, Yamashita 2004, Parlevliet et al. 2006) including the mature boar (Carpino et al. 2004, Pearl et al. 2006). Although the immature boar epididymis was previously reported to be negative for ERß (Carpino et al. 2004), our results demonstrate that $E R \beta$ is expressed in the boar epididymis throughout development. In most species, including the newborn pig, ER $\alpha$ was localized only to the efferent ducts while the epididymis is negative (Fisher et al. 1997, Goyal et al. 1997b, Nielsen et al. 2001, Nie et al. 2002, Hess \& Carnes 2004). In this study, ER $\alpha$ was localized to all three regions with fewer cells being positive in the corpus and cauda of 8 month animals as is the case in the mature boar, in which the corpus has only a few positive cells and the cauda is negative (Pearl et al. 2006). This suggests that estrogenic effects mediated through ER $\alpha$ in the cauda are necessary during development but not for mature function. The expression of $E R \alpha, E R \beta$, and $A R$ protein reported here suggests that estrogen, in addition to androgen, has a role throughout the development of the boar epididymis. The delay in development observed in our treated animals also suggests that estrogen is important for development in the boar but the mechanism by which estrogen acts requires further investigation.

In conclusion, ERs and ARs were expressed in the efferent ducts and all three epididymal regions throughout development suggesting that these tissues may be regulated by both estrogens and androgens in the boar. The lack of difference in receptor expression for $E R \alpha$ and ER $\beta$ suggests that ER expression in the boar efferent ducts and epididymis may be regulated by factors other than estrogen. Morphological development of the epididymis was delayed in Letrozole-treated boars suggesting that estrogen, directly or indirectly, affects normal morphological development of the epididymis. Efferent duct morphology and ER protein expression were unaffected by Letrozole treatment suggesting that the normally high endogenous levels of estradiol are not required for regulation of fluid reabsorption. If ER activation is important for regulation of fluid reabsorption in the porcine efferent ducts, receptor activation can be maintained in the absence of normal physiological levels of estradiol. This could explain why the efferent duct phenotype of Letrozole-treated boars in this study, which has similarities to ARKO mice, differs from the phenotype of $\alpha$ ERKO mice.

\section{Materials and Methods}

\section{Animal treatment and tissue collection}

Twenty-eight littermate pairs of boars were treated orally with either vehicle (corn oil) or with a nonsteroidal aromatase inhibitor $(0.1 \mathrm{mg} / \mathrm{kg}$ bodyweight Letrozole; CGS 20267; 4-4'(1 H-1,2,3-triazol-1-yl-methylene)-bis-benzonitrile; CibaGeigy, Basel, Switzerland) once a week starting at 1 week of age until castration at 2-7, or 8 months (At-Taras et al. 2006a, $2006 b)$. This study was conducted in accordance with the Guide for the Care and Use of Agricultural Animals in Agricultural Research and Teaching and approved by the Animal Use and Care Advisory Committee at the University of California at Davis. Boars were from established lines developed from Durocs, Hampshires, Yorkshires, and Pietrains provided by PIC USA (a division of Sygen International, Franklin, KY, USA) and housed at the UC Davis swine facility. Testicular aromatase activity, testicular steroid concentrations, and systemic steroid concentrations for these animals have previously been reported (At-Taras et al. 2006a).

Four littermate pairs ( $n=4$ control and $n=4$ treated) were castrated at each age; efferent ducts and epididymides were collected at castration. Epididymides were divided into three regions (caput, corpus, and cauda) based on previous studies (Syntin et al. 1996, 1999). Portions of efferent ducts and each epididymal region were fixed in $4 \%$ paraformaldehyde for immunocytochemistry (ICC) and morphology measurements or snap frozen in liquid nitrogen and stored at $-80{ }^{\circ} \mathrm{C}$ until processing for determination of steroid concentrations and mRNA quantification.

\section{Steroid concentrations}

Samples $(0.5-1 \mathrm{~g})$ were thawed at room temperature and minced into small pieces $\left(\sim 1 \mathrm{~mm}^{3}\right)$. Minced tissue was homogenized in $2 \mathrm{ml} \mathrm{PBS}$ for 1.5-2 min (Barnant Mixer, series 10, Chicago, IL, USA). The homogenate was centrifuged at 2271 g (Sorvall RT600B; Dupont; Wilmington, DE, USA) for $15 \mathrm{~min}$; the supernate was centrifuged again at $13500 \mathrm{~g}$ (MiniSpin plus; Eppendorf, Westbury, NY, USA) for $15 \mathrm{~min}$ to remove any remaining unhomogenized tissue. The final supernate was stored at $-20{ }^{\circ} \mathrm{C}$ until analysis for testosterone, estradiol, and total protein concentration. 


\section{Testosterone}

Epididymal tissue concentrations of testosterone were determined by a RIA previously validated for the pig (At-Taras et al. 2006a, Pearl et al. 2006). The RIA used a sheep antitestosterone antibody (Niswender \#S250; G Niswender, Colorado State University, Fort Collins, CO, USA), $\left[{ }^{3} \mathrm{H}\right]$ testosterone (testosterone 1, 2, 6, 7, [ $\left.{ }^{3} \mathrm{H}\right]$, NET370; Perkin-Elmer Life Sciences, Boston, MA, USA), and testosterone standards (A6940; Steraloids, Wilton, NH, USA). Samples were extracted with ethyl ether (Fisher Scientific, Pittsburgh, PA, USA); extraction efficiency was $90 \%$. Assay sensitivity was $0.1 \mathrm{ng} / \mathrm{ml}$. Intra- and inter-assay coefficients of variation were $5.4 \%(n=6)$ and $13.1 \%(n=5)$ respectively.

\section{Estradiol-17 $\beta\left(E_{2}\right)$}

Epididymal tissue concentrations of $E_{2}$ were determined using a RIA previously validated for the pig (At-Taras et al. 2006a). The RIA used a sheep anti-estradiol 17 $\beta-6-B S A$ antibody (Niswender no. 224), ${ }^{3} \mathrm{H}-\mathrm{E}_{2}$ (Perkin-Elmer Life Sciences, NET-317), and estradiol standards (E950; Steraloids). Samples were extracted with ethyl ether (Fisher Scientific); extraction efficiency was 90\%. Assay sensitivity was $6.25 \mathrm{pg} / \mathrm{ml}$. Intra- and inter-assay coefficients of variation were $6.0 \%$ $(n=6)$ and $13.3 \%(n=5)$ respectively.

\section{Protein concentration}

Total protein concentration of each sample was determined by the Bio-Rad protein assay (Bio-Rad Laboratories) using Stanbio total protein standard (Fisher Scientific). Protein concentration was used to normalize steroid values.

\section{Morphology assessment}

Tissue was paraffin embedded, sectioned at a thickness of $5 \mu \mathrm{m}$ and stained with hematoxylin and eosin. Five different tubule cross sections from each region (efferent duct, caput, corpus, and cauda) of each animal were photographed using a QImaging Micropublisher 3.3 digital camera and QCapture Pro software (QImaging Corporation, Burnaby, BC, Canada). Images of each tubule cross section were measured for tubule diameter, lumen diameter, and epithelial height. Tubule and lumen diameter were measured in two different places within each cross section, and epithelial height was measured in five different places within each cross section and averaged.

\section{Immunocytochemistry}

The localization of $E R \alpha, E R \beta$, and AR in the efferent duct, caput, corpus, and cauda was investigated by ICC (Pearl et al. 2006). Tissue was paraffin embedded and sectioned at a thickness of $5 \mu \mathrm{m}$. Antigen retrieval was performed by placing slides in Coplin jars in a steamer and heating to $93{ }^{\circ} \mathrm{C}$ for $\mathrm{AR}$ and $\mathrm{ER} \beta$. Slides were kept at $93{ }^{\circ} \mathrm{C}$ for $5 \mathrm{~min}$ and then allowed to cool to room temperature. ICC for $\mathrm{ER} \alpha$ was performed on sections without antigen retrieval. Tissues were incubated overnight at $4{ }^{\circ} \mathrm{C}$ with rabbit anti-human AR (1:1000; Santa Cruz Biotechnology, Santa Cruz, CA, USA) or mouse anti-human ERß (1:40; Serotec, Raleigh, NC, USA), or for $2 \mathrm{~h}$ at room temperature with rabbit anti-mouse ER $\alpha$ (1:250; Santa Cruz Biotechnology). Following primary antibody incubation, sections were incubated with species appropriate biotinylated secondary antibody followed by an avidin-biotin-horseradish peroxidase complex (ABC reagent). Immunostaining was visualized using 3-amino-9ethylcarbazol (AEC; $\mathrm{AR}$ and $\mathrm{ER} \alpha$ ) or 3,3'-diamnobenzidine (DAB; ER $\beta$ ) chromagen and evaluated by light microscopy. Sections of each region incubated with normal rabbit serum (NRS; AR and $E R \alpha$ ) or mouse $\lg G(E R \beta)$ instead of primary antibody were used as negative controls.

\section{mRNA analysis}

To confirm the results of ICC, quantification of mRNA for $E R \alpha, E R \beta$, and $A R$ in the efferent duct and epididymis in 2and 8-month boars was performed using Taqman PCR at the Lucy Whittier Molecular and Diagnostic Core Facility (University of California, Davis, CA, USA). For each receptor gene, final quantification was done using the comparative CT method (User Bulletin \#2, Applied Biosystems, Foster City, CA, USA) and is reported as the $n$-fold difference relative to a calibrator (average value of control boars). The housekeeping gene GAPDH was used to normalize the CT values of each target gene. Final values for $E R \alpha, E R \beta$, and $A R$ mRNA in Letrozole-treated boars are $n$-fold different from control boars.

\section{Western blotting}

To verify if differences in ER $\alpha$ mRNA correlated with $E R \alpha$ protein in the efferent ducts, protein levels of $E R \alpha$ in the efferent ducts of 8 -month animals ( $n=4$ pairs) were determined. Solubilized proteins from homogenized efferent ducts were separated on a SDS-polyacrylamide gel with a Hoefer Mighty Small II System (GE Healthcare; Piscataway, NJ, USA) using Multi Mark molecular weight standards (Invitrogen) and transferred to an Immobilon-P membrane (Millipore, Bedford, MA, USA). Membranes were incubated with normal donkey serum (Animal Science Horse Barn, UC Davis, CA, USA) for $1 \mathrm{~h}$ to block non-specific binding followed by primary antibody (ER $\alpha, 1: 200$; actin, 1:1500, Santa Cruz Biotechnology) incubation overnight at $4{ }^{\circ} \mathrm{C}$. The next day, membranes were washed and incubated for $1 \mathrm{~h}$ with horse-radish peroxidase conjugated donkey anti-rabbit secondary antibody (Jackson Immunoresearch, West Grove, PA, USA). Bound antibody was visualized with chemiluminescence (Western Lightning; Perkin-Elmer) and exposed on SuperRx film (Fisher Scientific).

\section{Statistical analysis}

All analyses were performed using the Mixed Models procedure of SAS (SAS version 9.1; Cary, NC, USA). The residuals were tested for normality and the data was normally distributed after natural log transformation. ANOVA were performed on the transformed data, which included main 
effects for age, region, and treatment. The effect of boar was considered a random effect to account for variation among animals. Comparisons were analyzed using the Tukey-Kramer multiple comparison test. Values are reported as least-squares means \pm pooled S.E.M.

\section{Acknowledgements}

This work was supported in part by National Research Initiative Competitive Grant no. 2002-35203-12606 from the USDA Cooperative State Research, Education, and Extension Service. We thank Dr Alan Conley for his advice and critical review of this manuscript. Also we thank Dr Tom Famula for help with statistics, Marci Jennings for RIAs and Barbara Nitta-Oda for Western blots. The authors declare that there is no conflict of interest that would prejudice the impartiality of this scientific work.

\section{References}

Asano K, Maruyama S, Usui T \& Fujimoto N 2003 Regulation of estrogen receptor alpha and beta expression by testosterone in the rat prostate gland. Endocrine Journal 50 281-287.

Atanassova N, McKinnell C, Williams K, Turner KJ, Fisher JS, Saunders PT, Millar MR \& Sharpe RM 2001 Age-, cell- and region-specific immunoexpression of estrogen receptor alpha (but not estrogen receptor beta) during postnatal development of the epididymis and vas deferens of the rat and disruption of this pattern by neonatal treatment with diethylstilbestrol. Endocrinology 142 874-886.

At-Taras EE, Conley AJ, Berger T \& Roser JF 2006a Reducing estrogen synthesis does not affect gonadotropin secretion in the developing boar. Biology of Reproduction 74 58-66.

At-Taras EE, Berger T, McCarthy MJ, Conley AJ, Nitta-Oda BJ \& Roser JF $2006 b$ Reducing estrogen synthesis in developing boars increases testis size and total sperm production. Journal of Andrology 27 552-559.

Calvo A, Pastor LM, Martinez E, Vazquez JM \& Roca J 1999 Age-related changes in the hamster epididymis. Anatomical Record 256 335-346.

Cardenas H \& Pope WF 2005 Estrogen receptors in the uterus and ovarian follicles of gilts treated with dihydrotestosterone. Domestic Animal Endocrinology 29 523-533.

Carpino A, Bilinska B, Siciliano L, Maggiolini M \& Rago V 2004 Immunolocalization of estrogen receptor beta in the epididymis of mature and immature pigs. Folia Histochemica et Cytobiologica $\mathbf{4 2}$ 13-17.

Cho HW, Nie R, Carnes K, Zhou Q, Sharief NA \& Hess RA 2003 The antiestrogen ICI 182, 780 induces early effects on the adult male mouse reproductive tract and long-term decreased fertility without testicular atrophy. Reproductive Biology and Endocrinology 157.

Coleman KM \& Smith CL 2001 Intracellular signaling pathways: nongenomic actions of estrogens and ligand-independent activation of estrogen receptors. Frontiers in Bioscience 6 D1379-D1391.

Conley AJ, Corbin CJ, Hinshelwood MM, Liu Z, Simpson ER, Ford JJ \& Harada N 1996 Functional aromatase expression in porcine adrenal gland and testis. Biology of Reproduction 54 497-505.

Ezer N \& Robaire B 2002 Androgenic regulation of the structure and function of the epididymis. In The Epididymis: From Molecules to Clinical Practice, pp 297-316. Eds B Robaire \& BT Hinton. New York: Kluwer Academic/Plenum Publishers.

Fisher JS, Millar MR, Majdic G, Saunders PT, Fraser HM \& Sharpe RM 1997 Immunolocalisation of oestrogen receptor-alpha within the testis and excurrent ducts of the rat and marmoset monkey from perinatal life to adulthood. Journal of Endocrinology 153 485-495.

Ford JJ 1983 Serum estrogen concentrations during postnatal development in male pigs. Proceedings of the Society for Experimental Biology and Medicine 174 160-164.

Goyal HO 1985 Morphology of the bovine epididymis. American Journal of Anatomy 172 155-172.
Goyal HO \& Williams CS 1991 Regional differences in the morphology of the goat epididymis: a light microscopic and ultrastructural study. American Journal of Anatomy 190 349-369.

Goyal HO, Bartol FF, Wiley AA \& Neff CW 1997a Immunolocalization of receptors for androgen and estrogen in male caprine reproductive tissues: unique distribution of estrogen receptors in efferent ductule epithelium. Biology of Reproduction 56 90-101.

Goyal HO, Bartol FF, Wiley AA, Khalil MK, Chiu J \& Vig MM $1997 b$ Immunolocalization of androgen receptor and estrogen receptor in the developing testis and excurrent ducts of goats. Anatomical Record 249 54-62.

Hayashi Y, Toda K, Saibara T, Okada T \& Enzan H 2006 Assessment of antiestrogenic activity of tamoxifen in transgenic mice expressing an enhanced green fluorescent protein gene regulated by estrogen response element. Biochimica et Biophysica Acta 1760 164-171.

Hess RA \& Carnes K 2004 The role of estrogen in testis and the male reproductive tract: a review and species comparison. Animal Reproduction 1 5-30.

Hess RA, Bunick D, Lee KH, Bahr J, Taylor JA, Korach KS \& Lubahn DB 1997 A role for oestrogens in the male reproductive system. Nature 390 509-512.

Kuiper GG, Carlsson B, Grandien K, Enmark E, Haggblad J, Nilsson S \& Gustafsson JA 1997 Comparison of the ligand binding specificity and transcript tissue distribution of estrogen receptors alpha and beta. Endocrinology 138 863-870.

Lee KH, Hess RA, Bahr JM, Lubahn DB, Taylor J \& Bunick D 2000 Estrogen receptor alpha has a functional role in the mouse rete testis and efferent ductules. Biology of Reproduction 63 1873-1880.

Lee KH, Finnigan-Bunick C, Bahr J \& Bunick D 2001 Estrogen regulation of ion transporter messenger RNA levels in mouse efferent ductules are mediated differentially through estrogen receptor (ER) alpha and ER beta. Biology of Reproduction 65 1534-1541.

Marquez DC, Lee J, Lin T \& Pietras RJ 2001 Epidermal growth factor receptor and tyrosine phosphorylation of estrogen receptor. Endocrine $\mathbf{1 6}$ 73-81.

McCarthy MJ, At-Taras EE, Pearl CA, Nitta-Oda BS, Roser JF, Conley AJ \& Berger T 2006 Suppression of endogenous estrogen during development affects porcine epididymal sperm maturation. Molecular Reproduction and Development 73 1122-1128.

Mutembei HM, Pesch S, Schuler G \& Hoffmann B 2005 Expression of oestrogen receptors alpha and beta and of aromatase in the testis of immature and mature boars. Reproduction in Domestic Animals $\mathbf{4 0}$ 228-236.

Nie R, Zhou Q, Jassim E, Saunders PT \& Hess RA 2002 Differential expression of estrogen receptors alpha and beta in the reproductive tracts of adult male dogs and cats. Biology of Reproduction $\mathbf{6 6}$ 1161-1168.

Nielsen M, Bogh IB, Schmidt M \& Greve T 2001 Immunohistochemical localization of estrogen receptor-alpha in sex ducts and gonads of newborn piglets. Histochemistry and Cell Biology 115 521-526.

O'Donnell L, Robertson KM, Jones ME \& Simpson ER 2001 Estrogen and spermatogenesis. Endocrine Reviews 22 289-318.

Oliveira CA, Carnes K, Franca LR \& Hess RA 2001 Infertility and testicular atrophy in the antiestrogen-treated adult male rat. Biology of Reproduction 65 913-920.

Oliveira CA, Carnes K, Franca LR, Hermo L \& Hess RA 2005 Aquaporin-1 and -9 are differentially regulated by oestrogen in the efferent ductule epithelium and initial segment of the epididymis. Biology of the Cell 97 385-395.

Parlevliet JM, Pearl CA, Hess MF, Famula TR \& Roser JF 2006 Immunolocalization of estrogen and androgen receptors and steroid concentrations in the stallion epididymis. Theriogenology $\mathbf{6 6}$ 755-765.

Pearl CA, Berger T \& Roser JF 2006 Estrogen and androgen receptor expression in relation to steroid concentrations in the adult boar epididymis. Domestic Animal Endocrinology (Epub ahead of print).

Picciarelli-Lima P, Oliveira AG, Reis AM, Kalapothakis E, Mahecha GA, Hess RA \& Oliveira CA 2006 Effects of 3-beta-diol, an androgen metabolite with intrinsic estrogen-like effects, in modulating the aquaporin-9 expression in the rat efferent ductules. Reproductive Biology and Endocrinology 451. 
Robertson KM, O'Donnell L, Jones ME, Meachem SJ, Boon WC, Fisher CR, Graves KH, McLachlan RI \& Simpson ER 1999 Impairment of spermatogenesis in mice lacking a functional aromatase (cyp 19) gene. PNAS 96 7986-7991.

Rodriguez CM, Kirby JL \& Hinton BT 2002 The development of the epididymis. In The Epididymis: From Molecules to Clinical Practice, pp 251-267. Eds B Robaire \& BT Hinton. New York: Kluwer Academic/Plenum Publishers.

Shayu D, Kesava CC, Soundarajan R \& Rao AJ 2005 Effects of ICI 182780 on estrogen receptor expression, fluid absorption and sperm motility in the epididymis of the bonnet monkey. Reproductive Biology and Endocrinology 310.

Stoffel MH \& Friess AE 1994 Morphological characteristics of boar efferent ductules and epididymal duct. Microscopic Research and Technique 29 411-431.

Stoffel M, Friess AE \& Kohler T 1991 Efferent ductules of the boar - a morphological study. Acta Anatomica 142 272-280.

Syntin P, Dacheux F, Druart X, Gatti JL, Okamura N \& Dacheux JL 1996 Characterization and identification of proteins secreted in the various regions of the adult boar epididymis. Biology of Reproduction $\mathbf{5 5}$ 956-974.

Syntin P, Dacheux JL \& Dacheux F 1999 Postnatal development and regulation of proteins secreted in the boar epididymis. Biology of Reproduction 61 1622-1635.
Toney TW \& Danzo BJ 1988 Developmental changes in and hormonal regulation of estrogen and androgen receptors present in the rabbit epididymis. Biology of Reproduction 39 818-828.

Yamashita S 2004 Localization of estrogen and androgen receptors in male reproductive tissues of mice and rats. Anatomical Record 279A 768-778.

Zhou Q, Clarke L, Nie R, Carnes K, Lai LW, Lien YH, Verkman A, Lubahn D, Fisher JS, Katzenellenbogen BS et al. 2001 Estrogen action and male fertility: roles of the sodium/hydrogen exchanger-3 and fluid reabsorption in reproductive tract function. PNAS 98 14132-14137.

Zhu LJ, Hardy MP, Inigo IV, Huhtaniemi I, Bardin CW \& Moo-Young AJ 2000 Effects of androgen on androgen receptor expression in rat testicular and epididymal cells: a quantitative immunohistochemical study. Biology of Reproduction 63 368-376.

Received 30 September 2006

First decision 27 November 2006

Revised manuscript received 21 June 2007

Accepted 10 July 2007 